\title{
Evaluation of biochemical and physiological responses of salsola spp at their natural habitats
}

\section{Doğal ortamlarında yetişen Salsola türlerinin biyokimyasal ve fizyolojik tepkilerinin araştırılması}

\author{
Sema KARAKAS $^{1 *}$ iD Murat DikiLitAS $^{2}$ iD , Mustafa ASLAN $^{3}$ iD Ayşe Nur GÜZEL $^{4}$ iD \\ ${ }^{1}$ Harran University, Faculty of Agriculture, Department of Soil Science and Plant Nutrition, Sanlıurfa, Turkey \\ ${ }^{2}$ Harran University, Faculty of Agriculture, Department of Plant Protection, Sanlıurfa, Turkey \\ ${ }^{3}$ Harran University, Faculty of Education, Division of Biology Education Sanlıurfa, Turkey \\ ${ }^{4}$ Harran University, Faculty of Agriculture, Department of Plant Protection, Sanlıurfa, Turkey
}

\section{To cite this article:}

Karakas, S., Dikilitas, M., Aslan, M. \& Güzel, A.N. (2019). Evaluation of biochemical and physiological responses of salsola spp at their natural habitats. Harran Tarım ve Gıda Bilimleri Dergisi, 23(2): 226-233.

DOI:

10.29050/harranziraat.474638

Address for Correspondence: Sema KARAKAS

e-mail:

skarakas@harran.edu.tr

Received Date

25.10.2018

Accepted Date:

14.03.2019

(C) Copyright 2018 by Harran University Faculty of Agriculture. Available on-line at www.dergipark.gov.tr/harranziraat

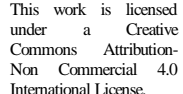

\section{ABSTRACT}

Halophytes are naturally salt-tolerant plants that are useful for soil remediation applications. Biochemical and physiological responses of Salsola species, namely; S. ruthenica, S. dendroides and $S$. crassa were evaluated at their natural habitats for their salt tolerance in which the biochemical responses such as peroxidase (POX, EC.1.11.1.7) and catalase (CAT, EC.1.11.1.6) enzymes, inorganic ion accumulation, proline (Pro), malondialdehyde (MDA), chlorophyll contents (Chl- $a, \mathrm{Chl}-b)$ were measured. The results showed that variation existed in Salsola spp. in their response to salinity. Although all Salsola spp. showed similar trends, S. ruthenica expressed higher activities of antioxidant enzymes along with the higher accumulation of proline, MDA contents than those of $S$. dendroides and $S$. crassa spp. Leaves of all three species exhibited high $\mathrm{Na}^{+}$content while $\mathrm{K}^{+}, \mathrm{Ca}^{++}$and $\mathrm{Mg}^{++}$contents are low. S. ruthenica accumulated $94.5 \mathrm{~g} \mathrm{~kg}^{-1} \mathrm{DW}$ of $\mathrm{Na}^{+}$ions while $S$. dendroides and $S$. crassa accumulated $82.1 \mathrm{~g}$ $\mathrm{kg}^{-1} \mathrm{DW}$ and $71.4 \mathrm{~g} \mathrm{~kg}^{-1} \mathrm{DW} \mathrm{Na}{ }^{+}$ions, respectively. The increase in enzymatic activities and higher metabolic contents and lower MDA levels in Salsola spp., especially in S. ruthenica, suggested that these species could well be used for phytoremediation purposes. With moderate height and root-length, these plants have high potentials to be used as companion plants with glycophytes to reduce salt stress in moderately saline conditions.

Key Words: Halophytes, Salsola spp., Enzymes, Salinity, Proline.

Öz

Halofit bitkiler toprak ıslahı uygulamaları için kullanılan doğal olarak tuza-tolerant bitkilerdir. Salsola türlerinin (S. ruthenica, S. dendroides ve S. crassa) tuz toleransına karşı biyokimayasal ve fizyolojik tepkileri doğal ortamlarında peroksidaz (POX, EC.1.11.1.7) ve katalaz (CAT, EC.1.11.1.6) enzimleri, inorganik iyon birikimi, prolin (Pro), malondialdehid (MDA) sentezi, ve klorofil içerkileri (Chl-a, Chl-b) gibi parametreler ölçülerek incelenmiştir. Sonuçlar, Salsola türlerinin tuza tepki bakımından farklılık olduğunu göstermiştir. Bütün Salsola türleri benzer tepkiler vermesine rağmen, $S$. ruthenica daha yüksek MDA, prolin ve antioksidan enzim ekspresyonları ile $S$. dendroides ve $S$. crassa türlerinden ayrılmıştır. Her üç türün yaprakları yüksek düzeyde $\mathrm{Na}^{+}$içerirken $\mathrm{K}^{+}, \mathrm{Ca}^{++}$ve $\mathrm{Mg}^{++}$içeriklerinde düşüş görülmüştür. S. ruthenica çeşidi $94.5 \mathrm{~g} \mathrm{~kg}^{-1} \mathrm{KA}$ of $\mathrm{Na}^{+}$iyonu içerirken $S$. dendroides ve $S$. crassa sırasıyla, $82.1 \mathrm{~g} \mathrm{~kg}^{-1} \mathrm{KA}$ ve $71.4 \mathrm{~g} \mathrm{~kg}^{-1} \mathrm{KA} \mathrm{Na}^{+}$iyonu içermektedir. Salsola türlerinde düşük MDA ve yüksek metabolit sentezi ile enzim artışları, özellikle $S$. ruthenica'de, bu türlerin fitoremediasyon çalışmaları için rahatlıkla kullanılabileceğini göstermiştir. Orta derecede tuzlu topraklarda tuz stresini azaltmak için ortalama boy ve kök uzunluğuna sahip bu bitkilerin arkadaş bitki olarak glikofitler ile birlikte kullanılma potansiyeli oldukça yüksektir.

Anahtar Kelimeler: Halofitler, Salsola spp., Enzimler, Tuzluluk, Prolin 


\section{Introduction}

Soil salinity is one of the most important plant growth limiting factors in arid and semi-arid areas as it does not only decrease the crop yield but also limits the distribution and variety of crop plants. However, there are plants which thrive under moderate and high saline conditions that most of the crop plants are not able to complete their life cycle (Acosta-Motos et al., 2017; Kaya and Inan, 2017). These plants are naturally saltadapted halophyte plants. Adaptation of halophytes to saline conditions is mostly associated with the osmoregulation adjustment that leads to the accumulation of various compounds such as free proline and sugars (Furtana et al., 2013; Meng et al., 2018). Salt tolerance mechanism in these plants is also maintained through morphological and physiological changes (Joshi et al., 2015). For example, a study carried out with Peganum harmala showed that this halophyte tolerated high salinity levels in which the most crop plants could not stand this plant accumulated necessary metabolites such as protein and proline to stand up to saline conditions (Dikilitas et al., 2007). In general, halophyte species (Atriplex spp., Peganum spp., Suaeda spp., Salsola spp., Chenopodium spp., Portulaca spp.) absorb the salt ions from the soil and metabolize them (Grieve and Suarez, 1997). To overcome salinity problem, several authors have been encouraged to use these biological traits to desalinize the soil via absorption of $\mathrm{Na}^{+}$ions through root system of halophytes in arid and semi-arid regions where low precipitations and inappropriate irrigation systems are unable to leach salts from the rhizosphere (Hasanuzzaman et al., 2014; Karakas et al., 2017). Soil phytodesalinization is based on the capacity of those halophyte plants.

Halophytes are the flora of saline soils (Flowers and Colmer, 2008). These plants osmotically adjust soil salinity by accumulating $\mathrm{Na}^{+}$and $\mathrm{Cl}^{-}$ ions and sequestering the great majority of these ions in their vacuoles while organic solutes are accumulated in cytoplasm to prevent the adverse effects on cell metabolism. At high salinities, however, growth is inhibited. The harmful effects of salinity may be attributed to the toxicity to metabolism of $\mathrm{Na}^{+}$and $\mathrm{Cl}^{-}$ions insufficient osmotic adjustment, reduced turgor, adverse cellular water relations in the apoplast, suboptimal levels of $\mathrm{K}^{+}$ions required for maintaining enzyme activities etc. (Flowers et al., 2015). Production of reactive oxygen species (ROS) and modifications in hormonal concentrations might also take great part. The capacity of defense mechanisms in such plants totally depends on the detoxification of these harmful species via antioxidant enzymes and non-enzymatic metabolites (Mittova et al., 2003).

Removal of salts by crop plants can significantly contribute to the phytoremediation process when harvested parts are not added back to the same soil. Phytoremediation is a low-cost technology that enhances plant-nutrient availability and extends the depth of ameliorated zone as well as promoting soil hydraulic properties (Qadir and Schubert, 2003; Gharaibeh et al., 2011).

Salsola species (Chenopodiaceae) contains worldwide as many as 150 species both with herbaceous and shrubby members (Willis 1973). It is a noxious bushy summer annual plant with rigid branches (Forbes and Allred, 1999). Salsola species have a great tolerance to water, heat and salt stress.

Halophyte plants growing near seashores have been collected since ancient times for food, for their medicinal qualities, and for their high salt contents (Tug and Yaprak, 2017). Increases in soil salinity have awakened new interest in plant species that possess inheritance in salt tolerance (Flowers et al., 2010). Scientists have studied with quite a few plant species for phytoremediation work so far (Jesus et al., 2015).

This study aimed to screen the Salsola spp. at their natural habitats to determine if there are any differences in terms of ion accumulation and biochemical responses among the species. Via this approach, we aimed to remediate the saline soils with the most promising species in our 
future work. Therefore, this study was centered on the evaluation of these species with regards to the activities of antioxidative enzymes, lipid peroxidation, and ion contents which might play significant roles for salt tolerance.

\section{Materials and Methods}

\section{Site location of soil samples}

Soils possessing high salinity levels were collected from the Harran Plain, Akçakkale Town $\left(36^{\circ} 42^{\prime \prime} 40^{\prime} \mathrm{N}-38^{\circ} 56^{\prime \prime} 53^{\prime} \mathrm{E}\right)$, Turkey (Figure 1), with 5 repetition from the root zone of Salsola spp. which they were identified as S. ruthenica, $S$. dendroides and S. crassa according to Davis et al., (1988). Salsola spp. along with soil samples were then transferred to the laboratory in ice containers for mineral and biochemical analyses there after. The samples were carefully air-dried to allow sieving with a 2-mm sieve. The electrical conductivity $(E C), \mathrm{pH}$, organic matter (OM), carbonate content, cation exchange capacity (CEC), exchangeable $\mathrm{Na}^{+}$cations, and soluble ions $\left(\mathrm{Na}^{+}, \mathrm{K}^{+}, \mathrm{Ca}^{++}, \mathrm{Mg}^{++}, \mathrm{Cl}^{-}\right)$amounts were determined from the saturation extract mud according to Richards (1954). Detailed chemical and physical properties of the soils are presented in Table 1.
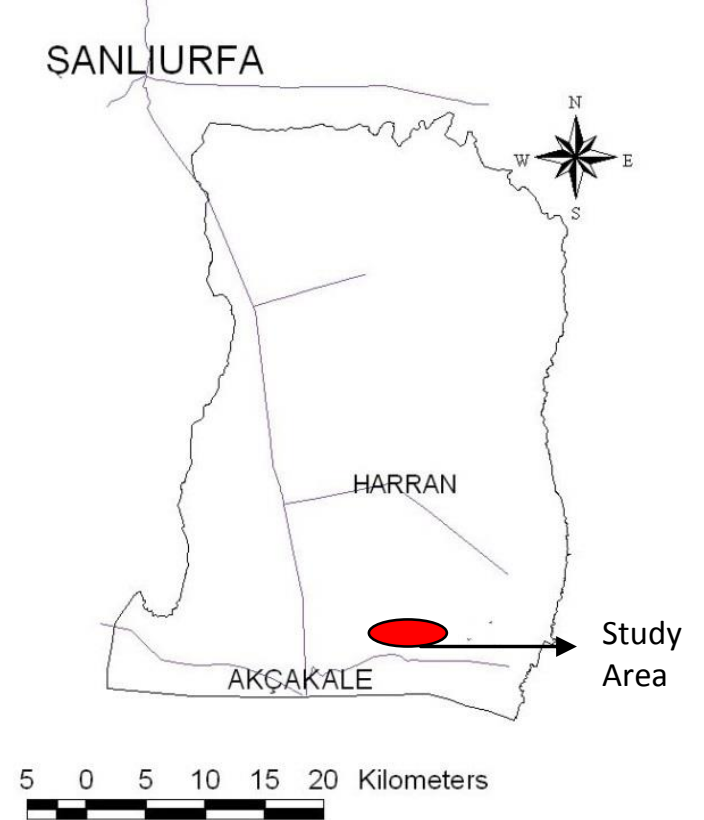

Figure 1. Study area in Harran plain Şekil 1. Harran platosunda çalışma alanı
Determination of Biochemical Parameters in the Plants

Chlorophyll contents of plants were determined according to the method of Arnon (1949). A $0.5 \mathrm{~g}$ leaf sample was homogenized in a $5 \mathrm{~mL}$ acetone: water (80:20, v:v) mixture and filtered through Whatman No.1 filter paper then placed in dark tubes. Chl $a, \mathrm{Chl} b$ and carotenoids of the plant samples were read at UV spectrophotometer (UV - 1700, Shimadzu) at $663.5 \mathrm{~nm}, 645 \mathrm{~nm}$ and $470 \mathrm{~nm}$, respectively against $80 \%$ acetone blank. The results were calculated as $\mathrm{mg} \mathrm{L}^{-1}$ fresh weight and expressed as $\mathrm{mg} \mathrm{g}^{-1}$ fresh weight according to the following formula.

$$
\begin{aligned}
& \text { Chlorophyll } a\left(\mathrm{mg} \mathrm{L}^{-1}\right)=12.7 A_{663.5}-2.69 A_{645} \\
& \text { Chlorophyll } b\left(\mathrm{mg} \mathrm{L}^{-1}\right)=22.9 A_{645}-2.69 A_{663.5}
\end{aligned}
$$

Proline determination was made using the procedure proposed according to Bates et al (1973). Fresh leaf samples $(0.5 \mathrm{~g})$ were homogenized in $3 \%$ sulfosalicylic acid and the homogenate was filtered through filter paper. Then, the filtrate was mixed in a test tube with acid-ninhydrin reagent and boiled at $100^{\circ} \mathrm{C}$ for one hour. The reaction was terminated in an ice bath. The mixture was extracted with toluene and the absorbance of the fraction with toluene aspired from the liquid phase was read Shimadzu UV by spectrometer at $515 \mathrm{~nm}$. Proline concentration was determined using calibration curve as $\mu \mathrm{mol}$ proline $\mathrm{g}^{-1}$ fresh weight.

Leaf samples (0.5) from each cultivar were homogenized with an ice-cold mortar and pestle with $5 \mathrm{~mL}$ of $50 \mathrm{mmol} \mathrm{L}^{-1} \mathrm{Na}$ - phosphate buffer (pH 6.5). The homogenates were centrifuged at $10,000 \mathrm{~g}$ for $10 \mathrm{~min}$ at $4{ }^{\circ} \mathrm{C}$. The supernatant was then used for the determination of enzymatic activities as well as protein contents.

Peroxidase enzyme activity (EC.1.11.1.7) was determined according to the method by Cvikrova et al (1994) with slight modifications (Karakas et al., 2016). For this, $100 \mu$ l extract was added to $2900 \mu \mathrm{l}$ reaction mixture (13 $\mathrm{mM}$ guaiacol, $5 \mathrm{mM}$ $\mathrm{H}_{2} \mathrm{O}_{2}$ and $50 \mathrm{mM} \mathrm{Na}$ - phosphate, $\mathrm{pH}$ 6.5). The 
reaction was initiated with a $\mathrm{H}_{2} \mathrm{O}_{2}$ addition and was measured at $470 \mathrm{~nm}$ using a UV spectrophotometer (UV-1700, Shimadzu) at oneminute interval until $3^{\text {rd }}$ minute. One unit of POX activity is defined as a change of 0.1 absorbance unit per minute at $470 \mathrm{~nm}$.

Catalase enzyme activity (EC.1.11.1.6) was determined according to the method of Milosevic and Slusarenko (1996) with slight modifications (Karakas et al., 2016). For the determination enzyme activity $50 \mu$ l supernatant was added to a $2950 \mu$ reaction mixture $\left(10 \mathrm{mM} \mathrm{H}_{2} \mathrm{O}_{2}, 50 \mathrm{mM}\right.$ Na-phosphate buffer and $4 \mathrm{mM} \mathrm{Na}{ }_{2}$ EDTA) and measured at $25^{\circ} \mathrm{C}$ with for 30 seconds internal at $240 \mathrm{~nm}$ for $1 \mathrm{~min}$ with a UV spectrometer (UV1700, Shimadzu).

The malondialdehyde (MDA) content was determined according to the method of Sairam and Saxena (2000) with using slight modifications. Fresh leaf tissue sample ( $0.5 \mathrm{~g})$ was homogenized in $0.1 \%$ trichloroacetic acid (TCA) and the homogenate was centrifuged at $10,000 \mathrm{~g}$ for 5 min. Thiobarbituric acid (TBA) $(0.5 \% \mathrm{v} / \mathrm{v})$ was added to $1 \mathrm{~mL}$ of the supernatant. The solution was heated at $95^{\circ} \mathrm{C}$ for $30 \mathrm{~min}$ then quickly cooled on ice. The mixture was centrifuged again at $10,000 \mathrm{~g}$ for $5 \mathrm{~min}$ and the absorbance of the clean supernatant was determined at 532 and $600 \mathrm{~nm}$. Here, the MDA content of leaves is expressed as nmol g ${ }^{-1}$ fresh tissue.

$\operatorname{MDA}\left(\mathrm{nmolg}^{-1}\right)=\frac{\text { Extract volume }(\mathrm{ml}) \times\left[\left(\mathrm{A}_{532}-\mathrm{A}_{600}\right) /\left(155 \mathrm{mM}^{-1} \mathrm{~cm}^{-1}\right)\right]}{\text { sample amount }(\mathrm{g})} \times 10^{3}$

Determination of mineral contents of Salsola spp.

The mineral contents $\left(\mathrm{Na}^{+}, \mathrm{K}^{+}, \mathrm{Ca}^{2+}, \mathrm{Mg}^{2+}\right)$ of leaves were determined according to the procedure of Chapman and Pratt (1961) with slight modifications (Karakas 2016). Dry plant samples (0.5) g were ground in a porcelain crucibles. The porcelain crucibles were placed into a muffle furnace, and the temperature was gradually increased up to $500{ }^{\circ} \mathrm{C}$. The cooled ash was then dissolved in $5 \mathrm{~mL} 2 \mathrm{~N}$ hydrochloric acid. After 30 minutes, the volume was made to $50 \mathrm{~mL}$ with distilled water and supernatant was filtered through Whatman No. 42 filter paper. Then resulting supernatant was analyzed via Inductively Coupled Plasma (ICP, Perkin Elmer).

Chloride of the plant samples was made following the method of Mohr by using $\mathrm{K}_{2} \mathrm{CrO}_{7}$ indicator. Amount of $\mathrm{Cl}$ was measured with the titration of $\mathrm{AgNO}_{3}$ (Johnson and Ulrich 1959, Kacar and Inal 2008).

The amount of $\mathrm{Na}^{+}$ions removed from the soil via Salsola spp. were calculated according to the equation made by Qadir et al. (2003):

$$
\mathrm{S}_{\text {ion-removal }}\left[\left(\mathrm{S}_{\text {ion-conc }}\right)\left(\mathrm{S}_{\mathrm{DW}}\right) / 10^{3}\right] / \mathrm{MW}_{\mathrm{Na}}
$$

Where, $\mathrm{S}_{\text {ion-removal }}$ is $\mathrm{Na}^{+}$removal through harvested plant ( $\mathrm{mmol}$ plant rhizosphere ${ }^{-1}$ ), $\mathrm{S}_{\text {ion- }}$ conc is the $\mathrm{Na}^{+}$concentration collected from plant leaves $\left(\mathrm{mg} \mathrm{kg}^{-1}\right), \mathrm{S}_{\mathrm{DW}}$ is the plant dry weight ( $\mathrm{g}$ plant), and $\mathrm{MW}_{\mathrm{Na}}$ is molecular weight of $\mathrm{Na}^{+}$. Then resulting removed salt is converted $\mathrm{kg}$ hectare.

\section{Statistical analysis}

Data were subjected to an analysis of variance (ANOVA) at a significance level of $P \leq 0.05$ using the Duncan's Multiple Range Test (DMRT) from the SPSS software program (Version 22.0, IBM). Data are presented as a mean value \pm the standard error.

\section{Results}

Determination soil physical and chemical characteristics in the study area

Soil physical and chemical characteristics, electrical conductivity (EC), $\mathrm{pH}$, calcareous, organic matters, cation exchange capacity (CEC), exchangeable $\mathrm{Na}^{+}$, exchangeable sodium percentage (ESP), texture (sand, silt, clay), soluble ions $\left(\mathrm{Na}^{+}, \mathrm{K}^{+} \mathrm{Ca}^{++}, \mathrm{Mg}^{++}\right.$and $\left.\mathrm{Cl}^{-}\right)$were determined from the soil samples. The results are summarized at Table 1. According to our findings, soil EC (shows the degree of salinity), $\mathrm{pH}$, calcite, ESP and CEC levels were found high while OM was found quite low. Soil texture was determined as clay. 
Table 1. Soil characteristics in the study area.

Çizelge 1. Çalışma alanındaki toprak özellikleri.

\begin{tabular}{|c|c|}
\hline Soil characteristics & Value \\
\hline $\mathrm{EC}\left(\mathrm{dS} \mathrm{m}^{-1}\right)$ & 27.4 \\
\hline $\mathrm{pH}$ & 7.9 \\
\hline calcareous (\%) & 25.9 \\
\hline OM (\%) & 1.1 \\
\hline $\mathrm{CEC}\left(\mathrm{cmol}_{\mathrm{c}} \mathrm{kg}^{-1}\right)$ & 43.5 \\
\hline Exchangeable $\mathrm{Na}$ (meq $100 \mathrm{~g}^{-1}$ ) & 14.3 \\
\hline ESP (\%) & 32.9 \\
\hline Sand (\%) & 20.5 \\
\hline Silt (\%) & 27.5 \\
\hline Clay (\%) & 52.0 \\
\hline Soluble $\mathrm{Na}^{+}\left(\right.$meq $\left.\mathrm{I}^{-1}\right)$ & 40.1 \\
\hline Soluble $\mathrm{Ca}^{++}\left(\mathrm{meq} \mathrm{I}^{-1}\right)$ & 24.3 \\
\hline Soluble $\mathrm{K}^{+}\left(\right.$meq $\left.{ }^{-1}\right)$ & 1.8 \\
\hline Soluble $\mathrm{Mg}^{++}\left(\mathrm{meq} \mathrm{I}^{-1}\right)$ & 8.3 \\
\hline Soluble $\mathrm{Cl}^{-}\left(\right.$meq I $\left.{ }^{-1}\right)$ & 38.7 \\
\hline
\end{tabular}

EC: Electrical conductivity, pH: Soil reaction , OM: Organic matter, CEC: Cation exchange capacity, ESP: Exchangeable sodium percentage.

\section{Changes biochemical parameters in the plants}

To determine the biochemical responses of Salsola spp. (S. ruthenica, S. dendroides and
S. crassa) chlorophyll, proline, MDA, CAT and POX levels were measured from the leaves of sampled plants.

When chlorophyll contents (Chl- $a, \mathrm{Chl}-b$ ) and carotenoids were examined, the highest $\mathrm{Chl} a$ and Chl $b$ were found in S. crassa as 1.3, 0.5 and 0.9 $\mathrm{mg} \mathrm{g}^{-1} \mathrm{FW}$, respectively, Table 2 . However when proline contents were evaluated, S. ruthenica synthesized the highest proline content as with $7.4 \mu \mathrm{mol} \mathrm{g}^{-1}$, S. dendroides and S. crassa synthesized 5.0 and $4.0 \mu \mathrm{mol} \mathrm{g}^{-1}$ proline, respectively.

MDA results showed that $S$. ruthenica had the highest MDA content with $37.3 \mathrm{nmol} \mathrm{g}^{-1} \mathrm{FW}$ $(P<0.05)$.

When antioxidant enzymes were measured, there were no significant differences among Salsola spp., however, S. ruthenica differed significantly from those of others in terms of CAT enzymes, $(P<0.05)$.

Table 2. The biochemical responses of the Salsola species at their saline habitats.

Çizelge 2. Doğal tuz ortamlarında Salsola türlerinin biyokimyasal tepkileri.

\begin{tabular}{|c|c|c|c|c|c|c|c|}
\hline \multirow[b]{2}{*}{ Salsola spp. } & \multicolumn{7}{|c|}{ Biochemical parameters } \\
\hline & $\begin{array}{c}\text { Chl- } a \\
\left(\mathrm{mg} \mathrm{g}^{-1}\right)\end{array}$ & $\begin{array}{c}\text { Chl-b } \\
\left(\mathrm{mg} \mathrm{g}^{-1}\right)\end{array}$ & $\begin{array}{c}\text { Carotenoid } \\
\left(\mathrm{mg} \mathrm{g}^{-1}\right)\end{array}$ & $\begin{array}{c}\text { Pro } \\
\left(\mu \mathrm{mol} \mathrm{g}^{-1}\right)\end{array}$ & $\begin{array}{c}\text { MDA } \\
\left(\mathrm{nmol} \mathrm{g}^{-1}\right)\end{array}$ & $\begin{array}{c}\text { CAT } \\
\text { (ünite } \mathrm{mg}^{-1} \text { ) }\end{array}$ & $\begin{array}{c}\mathrm{POX} \\
\text { (ünite } \mathrm{mg}^{-1} \text { ) } \\
\end{array}$ \\
\hline S. ruthenica & $0.9 \pm 0.1^{b}$ & $0.3 \pm 0.0^{c}$ & $0.5 \pm 0.0^{b}$ & $7.4 \pm 1.0^{\mathrm{a}}$ & $37.3 \pm 1.5^{\mathrm{a}}$ & $0.8 \pm 0.0^{\mathrm{a}}$ & $11.7 \pm 2.1^{\mathrm{a}}$ \\
\hline S. dendroides & $1.0 \pm 0.0^{b}$ & $0.4 \pm 0.1^{b}$ & $0.7 \pm 0.1^{b}$ & $5.0 \pm 2.0^{b}$ & $30.0 \pm 1.1^{b}$ & $0.4 \pm 0.0^{b}$ & $0.9 \pm 0.6^{a}$ \\
\hline S. crassa & $1.3 \pm 0.1^{\mathrm{a}}$ & $0.5 \pm 0.1^{a}$ & $0.9 \pm 0.0^{a}$ & $4.0 \pm 1.0^{b}$ & $26.7 \pm 1.5^{b}$ & $0.4 \pm 0.0^{b}$ & $8.0 \pm 0.5^{a}$ \\
\hline $\begin{array}{l}\text { Significance } \\
\text { level }\end{array}$ & $0.04^{*}$ & $0.00 * *$ & $0.03 *$ & $0.00 * *$ & $0.02 *$ & $0.01 *$ & $0.22^{\mathrm{NS}}$ \\
\hline
\end{tabular}

$\mathrm{Na}^{+}$Removal capacity of Salsola spp.

Salsola spp. (S. ruthenica, S. dendroides and S. crassa) accumulated high concentrations of salt ions their leaves. S. ruthenica accumulated 94.5 $\mathrm{Na}^{+} \mathrm{g} \mathrm{kg}^{-1}$ DW leaf ash while $S$. dendroides had $82.1 \mathrm{~g} \mathrm{~kg}^{-1}$ and $S$. crassa had $71.4 \mathrm{~g} \mathrm{~kg}^{-1} \mathrm{Na}^{+}$ions. Accumulation of $\mathrm{Na}^{+}$ions in leaves of $\mathrm{S}$. ruthenica had significantly higher when compared to those of others $(P<0.05$, Table 3$)$.

When other ions $\mathrm{K}^{+}, \mathrm{Ca}^{++}$were examined, $S$. ruthenica had lower concentrations than $S$. dendroides and S. crassa. While $\mathrm{Mg}^{++}$contents did not differ significantly among Salsola spp. It was observed that $\mathrm{Na}^{+}$and $\mathrm{K}^{+}$ions had an antagonistic relationship. Therefore, maintenance of salt tolerance depends on the balance between $\mathrm{Na}^{+}$ and $\mathrm{K}^{+}$ion contents. In our study, this level was observed in Salsola spp. When salt removal capacity of Salsola spp. was evaluated, $S$. ruthenica removed more salt as $\mathrm{NaCl}$ from the soil as with $787.8 \mathrm{~kg} \mathrm{ha}^{-1}$ when compared to those of S. dendroides and S. crassa as with 684.2 and $595.2 \mathrm{~kg} \mathrm{ha}^{-1}$, respectively, from the saline habitat $(P<0.05$, Table 3$)$. This clearly showed that Salsola spp. had remarkable potentials in removing salts from saline areas. Only, the differences were existed among the species evidencing that $S$. ruthenica had more capacity to remove salt from the saline habitat. 
Table 3. Ion contents of Salsola spp. and their salt removal value.

Çizelge 3. Salsola türlerinin ion içerikleri ve tuz uzaklaştırma değerleri.

\begin{tabular}{|c|c|c|c|c|c|c|}
\hline \multirow{2}{*}{ Salsola spp. } & \multicolumn{5}{|c|}{$\begin{array}{l}\text { Plant ion content } \\
\left(\mathrm{g} \mathrm{kg}^{-1}\right)\end{array}$} & \multirow{2}{*}{$\begin{array}{l}\text { Salt Removal } \\
\quad\left(\mathrm{kg} \mathrm{ha}^{-1}\right)\end{array}$} \\
\hline & $\mathrm{Na}^{+}$ & $\mathrm{K}^{+}$ & $\mathrm{Ca}^{++}$ & $\mathrm{Mg}^{++}$ & $\mathrm{Cl}^{-}$ & \\
\hline S. ruthenica & $94.5 \pm 1.4^{\mathrm{a}}$ & $7.8 \pm 1.0^{\mathrm{a}}$ & $5.7 \pm 0.6^{a}$ & $1.3 \pm 0.2^{\mathrm{a}}$ & $80.0 \pm 1.5^{a}$ & $787.8 \pm 12^{\mathrm{a}}$ \\
\hline S. dedtroides & $82.1 \pm 1.2^{b}$ & $11.1 \pm 1.1^{b}$ & $6.9 \pm 0.7^{b}$ & $1.4 \pm 0.1^{\mathrm{a}}$ & $65.0 \pm 2.0^{b}$ & $684.2 \pm 10^{b}$ \\
\hline S. crassa & $71.4 \pm 2.7^{c}$ & $12.3 \pm 1.4^{b}$ & $8.7 \pm 0.9^{b}$ & $1.8 \pm 0.1^{\mathrm{a}}$ & $60.0 \pm 2.5^{b}$ & $595.2 \pm 22^{c}$ \\
\hline Significance level & $0.00 * *$ & $0.05^{*}$ & $0.05^{*}$ & $0.10^{\mathrm{NS}}$ & $0.00 * *$ & $0.00 * *$ \\
\hline
\end{tabular}

\section{Discussion}

In this study, all Salsola spp. synthesized CAT, POX, MDA and proline to reduce the impact of salt stress. There are distinct differences between species. Once plants were suffered from salt stress, free radicals would be accumulated, membrane permeability would be distorted and would not function properly and lose its selectivity. To prevent these occurrences, plants have to produce metabolites to remediate the physiological and biochemical disorders. For example, high concentrations of salts cause ion imbalance and hyperosmotic stress in plants (Tipirdamaz et al., 2006; Akhtar and Yun., 2017). It was previously reported that an increase in $\mathrm{Na}^{+}$ ion levels led to decrease in $\mathrm{K}^{+}$ion concentration (Keisham et al., 2018). To ease the stress conditions, plants have to metabolize antioxidant molecules as well as accumulating toxic ions. In the case of halophytes, the accumulation of salt ions are in the prime importance when compared to the syntheses of other antioxidant molecules and enzymes. Because, halophytes are able to accumulate and metabolize salt ions rather than excluding them. Therefore, capacity of salt accumulation indicates the level of salt tolerance of the halophyte. In this study, we measured the stress-related metabolites and enzymes to see the level of stress tolerance. In our findings, Salsola spp. accumulated salt ions $\left(\mathrm{Na}^{+}, \mathrm{Cl}^{-}\right)$in their leaves on the other hand. $\mathrm{K}^{+}$and $\mathrm{Mg}^{++}$ions contents decreased. Accumulating $\mathrm{K}^{+}, \mathrm{Ca}^{++}$and $\mathrm{Mg}^{++}$ion in leaves of Salsola spp. made them tolerant to salinity. In our study, S. ruthenica was selected as the most promising salt tolerant candidate for remediation of saline soils. In contrast to $\mathrm{Na}^{+}$and $\mathrm{Cl}^{-}$ions, did not find any differences between leaf types and morphological characteristics in Salsola spp. suggesting that additional traits which regulate salt tolerance mechanisms may be involved in controlling $\mathrm{Na}^{+}$ and $\mathrm{K}^{+}$homeostasis.

This and similar other attributes led researchers to suggest that halophytes could be grown in salt-affected soils to remove significant amounts of $\mathrm{Na}^{+}$and $\mathrm{Cl}^{-}$ions through their aerial parts (Karakas et al., 2017). It is important to note that vegetative life determines the contents of salt ions in halophyte species. Here, the vegetative life of Atriplex spp. is much longer than those of Salsola spp. Therefore, higher accumulation of ions in Atriplex spp. is likely to happen. For example, Atriplex species grown under rangeland conditions have $\mathrm{Na}^{+}$ion contents in the range of $130-270 \mathrm{~g} \mathrm{~kg}^{-1}$ leaf ash (Hyder, 1981) and when grown in saline soils. The species accumulated as high as $390 \mathrm{~g} \mathrm{~kg}^{-1} \mathrm{Na}^{+}$ions in leaf ash (Malcolm et al., 1988).

Halophytes accumulating sodium salts in their shoots could be successfully used for the removal of sodium from the substrates on which they are grown, Karakas et al., (2017) estimated that Salsola sada L. and Portulaca oleracea L. were capable of removing $709 \mathrm{~kg} \mathrm{ha}^{-1}$ and $286 \mathrm{~kg} \mathrm{ha}^{-1}$, respectively. Salt accumulator plants could be very useful in saline areas.

Abiotic and biotic stress factors result in the generation of ROS such as $\mathrm{O}_{2}^{-}$and $\mathrm{H}_{2} \mathrm{O}_{2}$ in plant cells ROS formation also accompanies normal metabolic processes in particular photosynthesis and respiration in all cellular compartments. To 
ameliorate the danger posed by the presence of cellular oxidants, plant cells have evolved complex defense mechanisms (Diwan et al., 2010; Dikilitas et al., 2011). Plants possess several mechanisms that detoxify $\mathrm{O}_{2}^{-}$and $\mathrm{H}_{2} \mathrm{O}_{2}$ called antioxidant systems. The primary components of antioxidant systems include non-enzymatic antioxidants (carotenoids, ascorbate, glutathione and tocopherols) and enzymes such as SOD, catalase, peroxidase (Dikilitas et al., 2011). In our experiments, we noticed that quite a high level of antioxidant enzymes and amino acids, e.g. proline were remarkably high when compared to those of Salsola spp. grown in low saline conditions (Heidari-Sharifabad and Mirzaie-Nodoushan., 2006; Karakas., 2013). Similar results were also obtained from those of Panahi et al. (2013) and Panahi et al. (2015) who studied Salsola arbuscula and Salsola orientalis in saline conditions.

As conclusions, these plants have been found to have significant potentials to remove salt from saline-polluted areas. These plants could grow together with glycophytes as companion plants in the same area due to its relatively short root systems compared to other halophytes in saline soils. We plan to test the performance of plants as they might have contribution to remove heavy metals and pesticide residues from the soil since they are able to synthesized high consecrations of antioxidant enzymes (CAT, POX) and low concentrations of stress molecules (MDA) when compared to those of glycophytes at the same conditions (Prasad et al., 2005; Singh et al. 2006 ).

\section{References}

Acosta-Motos, J.R., Hernández, J.A., Álvarez, S., Barba-Espín, G., \& Sánchez-Blanco, M.J. (2017). Long-term resistance mechanisms and irrigation critical threshold showed by Eugenia myrtifolia plants in response to saline reclaimed water and relief capacity. Plant Physiol Biochemistry, 111, 244-256.

Akhtar A., \& Yun D.J., (2017). Salt Stress Tolerance; What Do We Learn From Halophytes? Journal of Plant Biology, 60, 431-439.

Arnon, D.L., (1949). A copper enzyme is isolated chloroplast polyphenol oxidase in Beta vulgaris. Plant Physiology, 24, 1-15.

Bates, L.S., Waldren, R.P., \& Teare, I.D., (1973). Rapid determination of free proline for water-stress studies. Plant and Soil, 39, 205-207.

Chapman, H.D., \& Pratt, P.F., (1961). Methods of analysis for soils, plants and waters. University of California, Division of Agricultural Sciences. USA, 1-309.

Cvikrova, M., Hrubcova, M., Vagner, M., Machackova I., \& Eder J. (1994) Phenolic acids and peroxidase activity in Alfalfa (Medicago sativa) embryogenic cultures after ethephon treatment. Plant Physiology, 91(2): 226-233.

Davis, P.H., Mill, R.R., \& Tan, K., (1988). Flora of Turkey and the East Aegean Islands. Edinburgh: Edinburgh University Press, Vol. 10 (Suppl. 1), 324-326.

Dikilitaş, M., Çullu, M. A., Karakaş, S., Aydemir, S., \& Saygan, E., (2007 May). Possible use of weeds fort he remediation of saline areas in GAP region and their biochemical responses to high level of salinity. Second Annual YOK-SUNY Collaboration Symposium. Scientific Collaboration For Sustainable Development (pp. 41-49), Adana, Turkey.

Dikilitas, M., Guldur, M.E., Deryaoglu, A., \& Erel O., (2011). A novel method of measuring oxidative stress of pepper (Capsicum annuum var. Charlee) infected with tobacco mosaic virus. Journal of Applied Biosciences, 37, 2425-2433.

Diwan, H., Khan, I., Ahmad, A., \& Iqbal, M., (2010). Induction of phytochelatins and antioxidant defence system in Brassica juncea and Vigna radiata in response to chromium treatments. Plant Growth Regulation, 61, 97-107.

Flowers, T.J., \& Colmer, T.D., (2008). Salinity tolerance in halophytes. New Phytology, 179, 945-963.

Flowers, T.J., Gaur, P.M., \& Gowda, C.L.L., (2010). Salt sensitivity in chickpea. Plant Cell and Environment, 33, 490-509.

Flowers, T.J., Munns, R., \& Colmer, T.D., (2015). Sodium chloride toxicity and the cellular basis of salt tolerance in halophytes. Annals of Botany, 115, 419431.

Forbes, A.C., \& Allred, K.W., (1999). An investigation of Salsola L. (Chenopodiaceae) in New Mexico. New Mexico Botany, 12, 2-9.

Furtana, G.B., Duman, H., \& Tipirdamaz, R., (2013). Seasonal changes of inorganic and organic osmolyte content in three endemic Limonium species of Lake Tuz (Turkey). Turkish Journal of Botany, 37, 455-463.

Gharaibeh, M.A., Eltaif, N.I., \& Albalasmeh, A.A., (2011). Eclamatıon of Highly Calcareous Saline Sodic Soil Using Atriplex Halimus and By-Product Gypsum, International Journal of Phytoremediation, 13, 873883.

Grieve, C.M., \& Suarez, D.L., (1997). Purslane (Portulaca oleracea L.): A Halophytic crop for drainage water reuse systems. Plant and Soil, 192, 277-283.

Hasanuzzaman, M., Nahar, K., Alam, Md. M., Prasanta C. Bhowmik, Hossain, Md. A., Rahman, M.M. Prasad, M.N.V., Ozturk, M., \& Fujita, M., (2014). Potential Use of Halophytes to Remediate Saline Soils. Journal of Biomedicine and Biotechnology, DOI, $10.1155 / 2014 / 589341$.

Heidari-Sharifabad, H., \& Mirzaie-Nodoushan, H., (2006). Salinity-induced growth and some metabolic changes in three Salsola species. Journal of Arid Environment, 


\section{$67,715-720$.}

Hyder, S.Z., (1981). Preliminary observations on the performance of some exotic species of Atriplex in Saudi Arabia. Journal of Range Management., 34, 208-210.

Jesus, J.M., Danko, A.S., Danko, A.S., Fiuza, A., \& Borges, M.T., (2015). Phytoremediation of salt-affected soils: a review of processes, applicability, and the impact of climate change. Environmental Science and Pollution Research. 22(9), 6511-25.

Johnson, C.M., \& Ulrich, A., (1959). II. Analytics methods for use in plant analysis. Bulletin of California Agricultural Experiment Station, 799.

Joshi R., Mangu, V.R., Bedre, R., Sanchez, L., Pilcher, W., Zandkarimi, H., \& Baisakh, N., (2015). Salt adaptation mechanisms of halophytes: Improvement of salt tolerance in crop plants, G.K. Pandey (ed.), Elucidation of Abiotic Stress Signaling in Plants, Springer Science Business Media New York, DOI, 10.1007/978-1-4939-2540-7_9.

Kacar, B., \& Inal, A., (2008). Plant analysis. Nobel publication and distribution Ankara, Turkey.

Karakas S., (2013). Development of tomato growing in soil differing in salt levels and effects of companion plants on same physiological parameters and soil remediation. PhD, University of Harran, of Agriculture, Department of Soil Science and Plant Nutrition, Sanlıurfa, Turkey.

Karakas, S., Cullu, M.A., \& Dikilitas, M., (2017). The salt removal potential of two halophyte species (Salsola soda and Portulaca oleracea) in saline soils. Turkish Journal Agriculture and Forestry, 41, 183-190.

Karakas, S., Cullu, M.A., Kaya, C., \& Dikilitas, M., (2016). Halophytic companion plants improve growth and physiological parameters of tomato plants grown under salinity. Pakistan Journal and Botany, 48, 2128.

Kaya, A., \& Inan, M., (2017). Tuz (NaCl) Stresine Maruz Kalan Reyhan (Ocimum basilicum L.) Bitkisinde Bazı Morfolojik, Fizyolojik ve Biyokimyasal Parametreler Üzerine Salisilik Asidin Etkileri. Harran Tarım ve Gıda Bilimleri Dergisi, 21(3), 332-342.

Keisham, M., Mukherjee, S., \& Bhatla, S.C., (2018). Mechanisms of Sodium Transport in PlantsProgresses and Challenges. International Journal of Molecular Sciences, 19, 647.

Malcolm, C.V., Clarke, A.J., \& D’Antuono, M.F., (1988). Effects of plant spacing and soil conditions on the growth of five Atriplex species. Agriculture Ecosystems and Environment, 21, 265-279.

Meng, X., Zhou, J., \& Sui, N., (2018). Mechanisms of salt tolerance in halophytes: current understanding and recent advances. Open Life Science, 13, 149-154.

Milosevic, N., \& Slusarenko, A.J., (1996). Active oxygen metabolism and lignification in the hypersensitive response in bean. Physiological and Molecular Plant Pathology, 49, 143-158.

Mittova, V., Tal, M., Volokita, M., \& Guy, M., (2003) Upregulation of the leaf mitochondrial and peroxisomal antioxidative systems in response to salt-induced oxidative stress in the wild salt-tolerant tomato species Lycopersicon pennellii. Plant Cell Environment, 26, 845-856.

Panahi, F., Asareh, M.H., Jafari, M., Givar, A., Tavili, A., Arzani, H., \& Ghorbani, M., (2015). The Responses of Salsola orientalis to Salt Stress. International Journal of Advanced Biological Research, 3 (2), 163-171.

Panahi, F., Assareh, M.H., Jafary, M., Mohseni Saravi, M., Givar, A., Arzani, H., \& Tavili, A., (2013). Salsola arbuscula Responses to Salt Stress. International Journal of Innovative Technology and Exploring Engineering, 3(5), 11-18.

Prasad, S.M., Kumar, D., \& Zeeshan, M., (2005). Growth, photosynthesis, active oxygen species and antioxidants responses of paddy field cyanobacterium Plectonema boryanum to endosulfan stress. Journal of General and Applied Microbiology, 51, 115-123.

Qadir, M., Steffens, D., Yan, F., \& Schubert, S., (2003). Sodium removal from a calcareous saline-sodic soil through leaching and plant uptake during phytoremediation. Land Degradation and Development, 14, 301-307.

Richards, L.A., (1954). Diagnosis and improvement of saline and alkali soils. US Salinity Lab., US Department of Agriculture Handbook 60. California, USA.

Sairam, R.K., \& Sexena, D., (2000). Oxidative Stress and antioxidants in wheat genotypes: possible mechanism of water stress tolerance. Journal of Agronom Crop Science, 184, 55, 345.

Singh, S., Eapen S., \& D'Souza, S.F., (2006). Cadmium accumulation and its influence on lipid peroxidation and antioxidative system in an aquatic plant Bacopa monnieri L. Chemosphere, 62, 233-246.

Tipirdamaz, R., Gagneul, D., Duhaze, C., Aınouche A., Monnier, C., Ozkum, D., \& Larher, F., (2006). Clustering of halophytes from an inland salt marsh in Turkey according to their ability to accumulate sodium and nitrogenous osmolytes. Environmental and Experimental Botany, 57, 139-153.

Tug, G.N., \& Yaprak, A.E., (2017). Halophytes as a Potential Food Source. Anadolu, J. AARI, 27 (2), 78-81.

Willis, J.C., (1973). A Dictionary of the flowering plants and ferns. Cambridge Univ. Press, Cambridge. Forbes, A.C., Allred, K.W. 1999. An investigation of Salsola L. (Chenopodiaceae) in New Mexico. New Mexico Botany, 12, 2-9. 